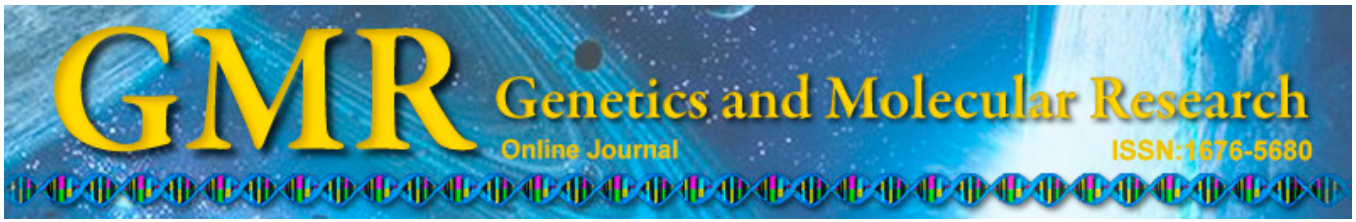

\title{
Sex identification based on AMEL gene PCR amplification from blue sheep (Pseudois nayaur) fecal DNA samples
}

\author{
X. Liu ${ }^{1}$, Y.Y. Yang ${ }^{1}$, X.M. Wang ${ }^{1}$, Z.S. Liu ${ }^{2}$, Z.H. Wang ${ }^{1}$ and Y.Z. Ding ${ }^{1}$ \\ ${ }^{1}$ Department of Biology, School of Life Sciences, East China Normal University, \\ Shanghai, China \\ ${ }^{2}$ Department of wildlife Conservation, School of Wildlife Resources, \\ Northeast Forestry University, Harbin, China \\ Corresponding author: Y.Z. Ding \\ E-mail: yzding@kj.ecnu.edu.cn
}

Genet. Mol. Res. 14 (3): 9045-9052 (2015)

Received October 15, 2014

Accepted April 6, 2015

Published August 7, 2015

DOI http://dx.doi.org/10.4238/2015.August.7.13

\begin{abstract}
The use of noninvasive genetic sampling to identify the sex of wild animals is an extremely valuable and important tool in molecular ecology and wildlife conservation. Sex determination using the amelogenin gene has been conducted in many species because only a single pair of primers is required to amplify both Xand Y-linked alleles. However, this method has not been used in field research with the feces of wildlife. In this study, we applied this method to 222 fecal samples from wild blue sheep (Pseudois nayaur) using amelogenin primers (SE47/SE48) after testing the effectiveness of sex determination using tissue samples and fecal samples from blue sheep of known sex. We found this method to be highly reliable (80.2\%) for blue sheep. Amelogenin can be used to identify the sex of wild animals using fecal samples.
\end{abstract}

Key words: Amelogenin; Fecal sample; Non-invasive genetic sample; Blue sheep; Polymerase chain reaction-based sex-typing 


\section{INTRODUCTION}

Identifying the sex of free ranging wildlife is a critical component in molecular ecology and conservation genetics (Griffiths et al., 1998; Schliebe et al., 1999). This information is essential for understanding population dynamics, dispersal, habitat use, population structure, and behavior (Mossman and Waser, 1999; Woods et al., 1999; Lucchini et al., 2002; Pajares et al., 2007). Because of the elusive behavior and rarity or lack of sexual dimorphism in many wildlife species, sex determination is difficult (Taberlet et al., 1993; Rosel, 2003). Feces is a non-invasive sample that is easy to collect and contains a large amount of ecological information (Waits and Paetkau, 2005; Brinkman and Hundertmark, 2009). The development of techniques that utilize DNA collected through non-invasive sampling from wild animals, particularly feces, has created new opportunities for sex determination in wildlife (Reed et al., 1997; Ding et al., 1998; Oliveira and Duarte, 2013).

In mammals, the sex-determining $S R Y$ and $Z f x / y$ genes (Griffiths and Tiwari, 1993; Taberlet et al., 1993) and the enamel protein gene for amelogenin (Chen et al., 1999; Yamauchi et al., 2000; Bradley et al., 2001; Ensminger and Hoffman, 2002; Di Fiore, 2005) have been used to identify sex. Of these, amelogenin $(A M E L)$ requires a single pair of primers only to amplify both X-and Y-linked alleles and shows a relatively large different in length between the X- and Y-chromosome fragments (Sullivan et al., 1993; Ennis and Gallagher, 1994; Yamauchi et al., 2000; Pfeiffer and Brenig, 2005).

Helan Mountain, China, forms a "continental island" for many wildlife species as it is separated from other pockets of suitable habitat by surrounding desert, cities, and rivers. Particularly, blue sheep (Pseudois nayaur) inhabiting this area comprise a special peripheral population with no immigration and emigration. The blue sheep population has increased in recent years, and how individuals will disperse to ensure that the population remains healthy and robust remains a significant issue in the management of this animal. Determining the sex of these wild animals is a central component of understanding their spatial ecology and population dynamics. In this study, we applied sex identification methods using the $A M E L$ gene using fecal samples collected from blue sheep. This method is frequently used for bovid tissue samples, but rarely for fecal samples, and may present an efficient method of sex identification in this remote species.

\section{MATERIAL AND METHODS}

\section{Samples}

Tissue samples extracted from the fur of wild blue sheep that died of natural causes of known sex $(\mathrm{N}=17)$ were used as positive controls and collected from Helan Mountain, Tibet, Qinghai, Gansu, and Xinjiang in 2011. Fecal samples of known sex $(\mathrm{N}=3)$ were collected from the Shanghai Zoo in 2013 and used to test the effectiveness of the AMEL primers. Fecal samples $(\mathrm{N}=222)$ from wild animals were also collected from Helan Mountain as part of an ongoing study of blue sheep. Sex identification was only performed for samples in which successful amplification of at least 1 microsatellite locus was achieved.

\section{DNA extraction and polymerase chain reaction (PCR) amplification}

We extracted DNA from feces using the E.Z.N.A. ${ }^{\mathrm{TM}}$ Stool DNA Kit (Omega Bio- 
Tek, Norcross, GA, USA) according to manufacturer protocols. DNA was amplified via PCR using the primers SE47 (5'-CAGCCAAACCTCCCTCTGC-3') and SE48 (5'-CCCGCTTGGTCTTGTCTGTTGC-3') as described previously (Ennis and Gallagher, 1994). We amplified the amelogenin segment from tissue and feces. According to this method, a male sample contains 2 bands in the agar gel, while a female sample contains 1 band. If 2 bands were found twice out of 6 runs, the fecal sample was regarded as being produced by a male; otherwise the sample was regarded as belonging to a female. PCR amplification was carried out in a total volume of $15 \mu \mathrm{L}$ consisting of $1.5 \mu \mathrm{L}$ DNA extract, $1.25 \mathrm{U}$ Premix Ex Taq, $0.5 \mu \mathrm{L} 20 \mathrm{mg} / \mathrm{mL}$ bovine serum albumin (Takara, Otsu, Japan), and $10 \mu \mathrm{M}$ of each primer (SE47, SE48). The PCR protocol consisted of a denaturing step at $94^{\circ} \mathrm{C}$ for $5 \mathrm{~min}$, followed by 35 cycles at $95^{\circ} \mathrm{C}$ for $30 \mathrm{~s}$, $62^{\circ} \mathrm{C}$ for $30 \mathrm{~s}$, and $72^{\circ} \mathrm{C}$ for $45 \mathrm{~s}$. Final extension was performed at $72^{\circ} \mathrm{C}$ for $7 \mathrm{~min}$. PCR products were separated by $2 \%$ agarose gel electrophoresis for $33 \mathrm{~min}$ and then photographed.

\section{RESULTS}

\section{Sex identification using tissue samples}

Every sample was scored as female or male based on the presence of amplification products of appropriate size by electrophoresis and all 17 samples of known sex were correctly typed (Table 1). PCR amplification in male and female animals consistently displayed a sexspecific band pattern showing length variations that were characteristic of AMELX and AMELY in all blue sheep analyzed (Figure 1).

Table 1. Sex identification using tissue samples from blue sheep of known sex.

\begin{tabular}{|c|c|c|c|c|}
\hline Sample ID & Sample & Origin of sample & Known sex & Determined sex \\
\hline HLS2 & Tissue & Helan Mountain & M & M \\
\hline HLS3 & Tissue & Helan Mountain & $\mathrm{F}$ & $\mathrm{F}$ \\
\hline HLS8 & Tissue & Helan Mountain & $\mathrm{F}$ & $\mathrm{F}$ \\
\hline HLS9 & Tissue & Helan Mountain & M & M \\
\hline HLS35 & Tissue & Helan Mountain & M & M \\
\hline HLS47 & Tissue & Helan Mountain & M & M \\
\hline G1 & Tissue & Gansu & M & M \\
\hline G3 & Tissue & Gansu & M & $\mathrm{M}$ \\
\hline LZ1 & Tissue & Tibet Linzhi & M & M \\
\hline NM1 & Tissue & Tibet Namucuo & $\mathrm{M}$ & M \\
\hline RT1 & Tissue & Tibet Rkaze & $\mathrm{F}$ & $\mathrm{F}$ \\
\hline QH1 & Tissue & Qinghai & $\mathrm{M}$ & M \\
\hline $\mathrm{QH} 2$ & Tissue & Qinghai & $\mathrm{M}$ & M \\
\hline $\mathrm{XJ} 1$ & Tissue & Xinjiang & M & M \\
\hline $\mathrm{XJ} 2$ & Tissue & Xinjiang & M & M \\
\hline $\mathrm{SC} 18$ & Tissue & Sichuan & $\mathrm{F}$ & $\mathrm{F}$ \\
\hline SC19 & Tissue & Sichuan & M & M \\
\hline
\end{tabular}

We cloned the PCR products from the collected tissue samples and observed PCR fragments specific to males (263 and 218 base pairs, bp) and females (263 bp). There was no difference in this length across different blue sheep populations (e.g., P. nayaur nayaur in Tibet and Pseudois nayaur szechuanensis in Qinghai, Gansu, Xinxiang, Sichuan, and Ningxia). Male and female blue sheep differed by $10 \mathrm{bp}$; the 2 amplicons differed in size by $45 \mathrm{bp}$ and were easily separated and visualized using bench-top procedures (Figure 2). 


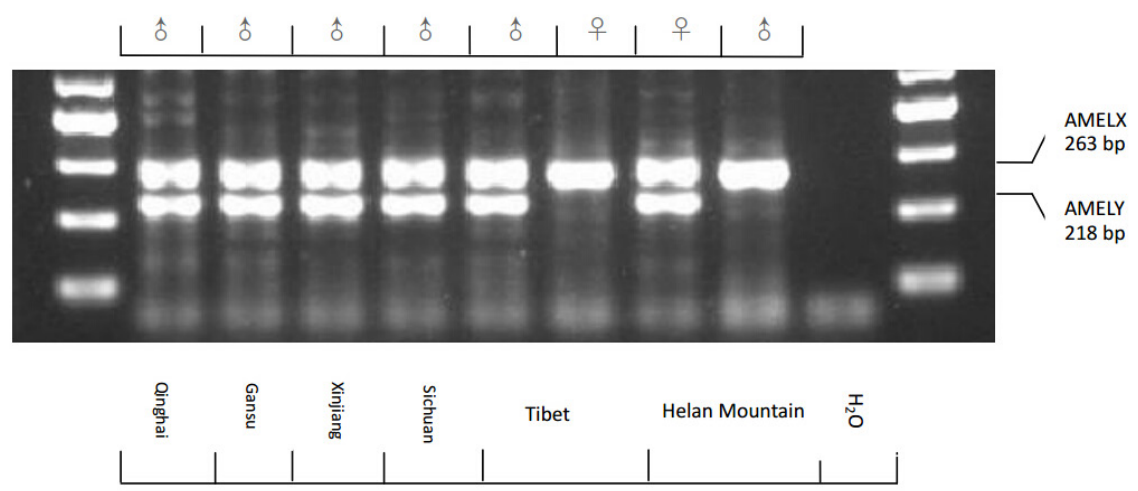

Figure 1. Sex identification based on amelogenin amplification (AMELX and $A M E L Y$ ) in blue sheep.

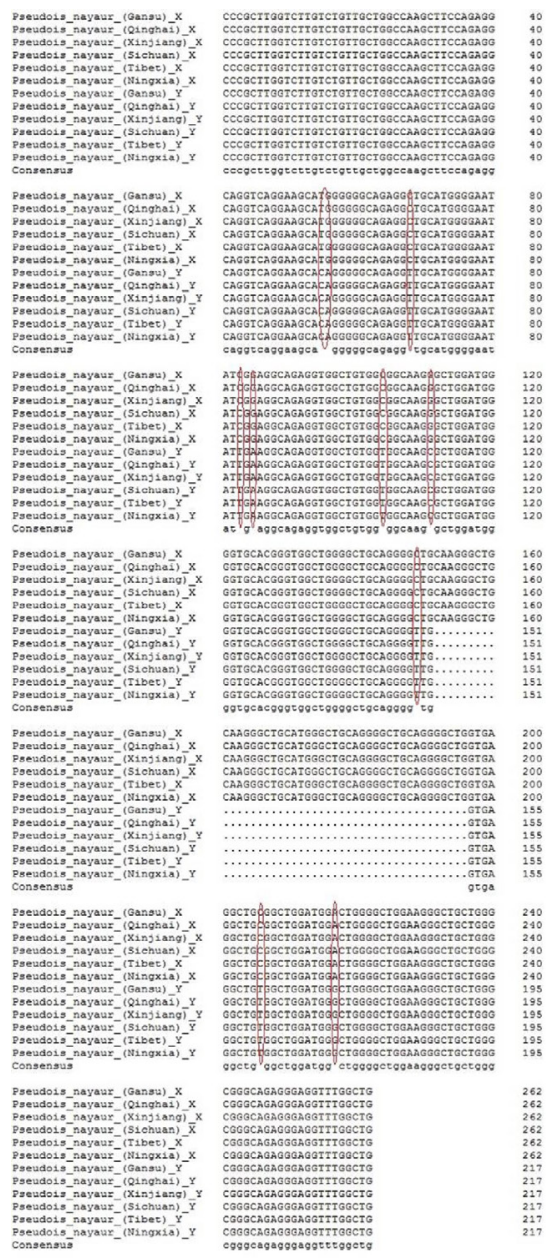

Figure 2. Alignment of female and male amelogenin sequences (AMELX and AMELY) from blue sheep inhabting six areas. Sequence variations are indicated by the circles. 


\section{Sex identification using fecal samples}

The results of sex identification using blue sheep fecal samples are shown in Table 2. We identified 98 samples as male and 124 samples as female. Based on these results, we determined the overall blue sheep sex ratio as 1.27:1 (ㅇ: $\left.{ }^{\Uparrow}\right)$. The sex ratio of blue sheep inhabiting Lülugou

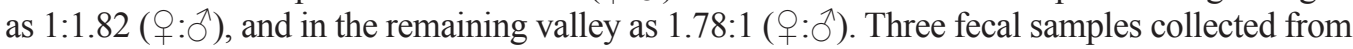
the Shanghai Zoo ( 2 males and 1 female) were also successfully amplified from samples collected from the field via PCR using the AMELX and AMELY gene primers 6 times (Figure $3 \mathrm{~A}$ and $\mathrm{B}$ ).

Table 2. Sex identification using 222 fecal samples from blue sheep inhabiting Helan Mountain, Nigxia, China.

\begin{tabular}{lccc}
\hline Location & Samples $(\mathrm{N}=222)$ & Males $(\mathrm{N}=98)$ & Females $(\mathrm{N}=124)$ \\
\hline Valley of Zihuagou & 11 & 4 & 7 \\
Valley of Gangou & 12 & 3 & 9 \\
Ridge between Zihuagou and Gangou & 23 & 3 & 20 \\
Valley of Gangoushui & 61 & 24 & 37 \\
Valley of Dananchi in Zizhuagou & 53 & 24 & 29 \\
Valley of branch road in Lvlugou & 62 & 40 & 22 \\
\hline
\end{tabular}
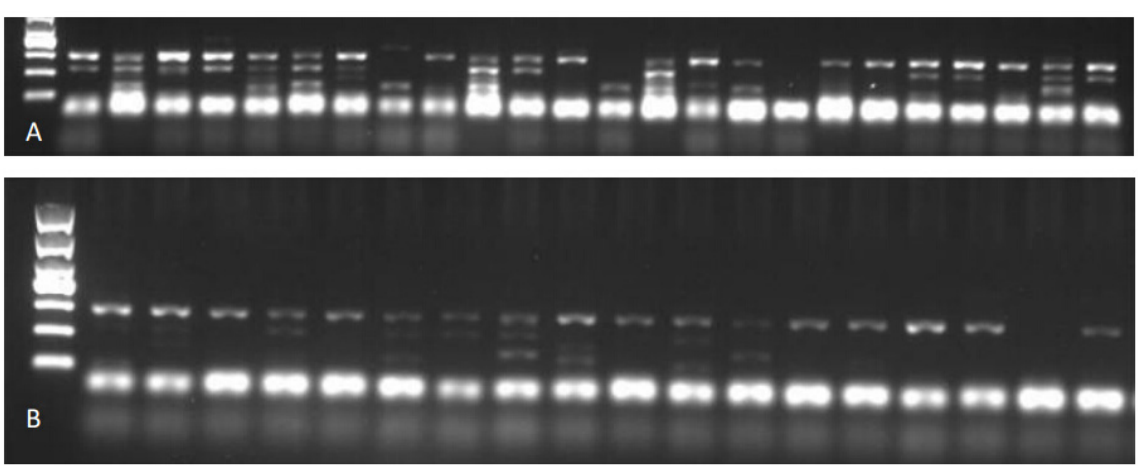

Figure 3. Blue sheep sex identification with $A M E L X / A M E L Y$ gene primers (SE-47, SE-48) fecal samples from Helan Mountain, Nigxia, (A) and fecal samples from Shanghai Zoo (B).

Although there were some non-specific bands or no bands present, these bands did not affect the results and thus the method used in this study was reliable.

Further, we analyzed the correct sex and the steady sex of tissue samples (from wild animals of known sex) and fecal samples (Shanghai Zoo animals of known sex); this data is presented in Table 3 and Figure 4.

Table 3. Correct sex and steady sex of all blue sheep samples.
\begin{tabular}{lccccc}
\hline Samples & $\begin{array}{c}\text { Total number } \\
\text { of samples }\end{array}$ & $\begin{array}{c}\text { Correctly sexed } \\
\text { (tested 6 times) }\end{array}$ & $\begin{array}{c}\text { Steady sexed } \\
\text { (tested 2 times) }\end{array}$ & $\begin{array}{c}\text { Steady sexed } \\
\text { (tested 4 times) }\end{array}$ & $\begin{array}{c}\text { Steady sexed } \\
\text { (tested 6 times) }\end{array}$ \\
\hline Tissue & 17 & 17 & 17 & 17 & 17 \\
Fecal samples from Shanghai Zoo & 3 & 3 & 3 & 3 & $2(66.6 \%)$ \\
Fecal samples from Helan Mountain & 222 & NA & $178(80.2 \%)$ & $80(36 \%)$ & $60(27 \%)$ \\
\hline
\end{tabular}

Correct sex: the sample amounts of the sex identification correctly determined (known sex tissue samples and feces samples). Steady sex: the number of samples with the same result repeated many times. 


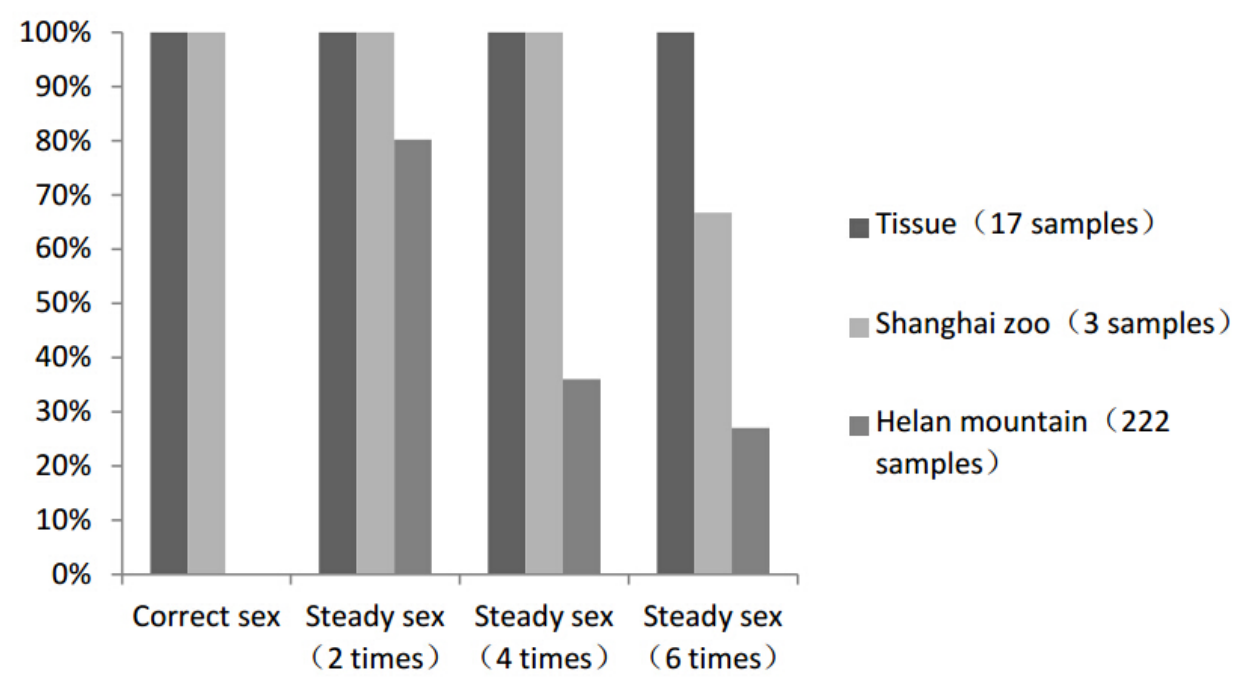

Figure 4. Correct sex and steady sex of all blue sheep samples in this study.

\section{DISCUSSION}

Under specific conditions, a lack of complementarity and allelic drop-out in low quality samples may lead to less efficient amplification of the $\mathrm{Y}$ chromosome fragment (Sipos et al., 2007; Bru et al., 2008; Gurgul et al., 2010) or generate non-specific products, resulting in misinterpretation of data. Other studies have shown that amplification of longer ( $>300 \mathrm{bp}$ ) fragments is problematic because of high amplification failure and allelic dropout (Buchan et al., 2005) when a small amount of DNA or a poor-quality template is used (Findlay and Quirke, 1996). This problem is more serious when using feces, hair, and other non-invasive samples. Methods based on fecal samples and $A M E L$ circumvent this problem by using fresh samples and targeting much smaller regions for amplification. Importantly, the target fragments are short and are reliably amplified, even when using degraded DNA templates recovered from non-invasive samples.

The target fragments of the primers used in this study were short, and fecal samples collected from wildlife inhabiting Helan Mountain were as fresh as possible, improving the reliability of the results. The method tested here correctly attributed the sex of $100 \%$ of animals using tissue samples and therefore can be used for sex identification in blue sheep. We compared tissue samples across the 6 populations, and found no difference in the $A M E L$ sequence across regions or between subspecies ( $P$. nayaur nayaur and $P$. nayaur szechuanensis).

While fecal amplification using $A M E L$ primers resulted in numerous extra bands, the target bands could be easily distinguished. Our accuracy rate of sex determination was $80.2 \%$ of samples over 2 trials, which is comparable to the success rate observed for the $S R Y$ primer (85\%) (Yamazaki et al., 2011). Further, the sex ratio detected here (1.27 female: 1 male) corresponded to the ratio found in other field studies of blue sheep inhabiting Helan Mountain (Wang et al., 1998; Cao, 2005; Liu et al., 2007). The sex ratio measured for animals inhabiting Lülugou $(q: \hat{O}=1: 1.82)$ and other valleys $(q: \hat{O}=1.78: 1)$ was consistent with the fact that males and females separate during the breeding season. 
In conclusion, our assessment of the $A M E L$ primer in blue sheep indicated that this method can be used to identify the sex of wild animals using fecal samples.

\section{Conflicts of interest}

The authors declare no conflict of interest.

\section{ACKNOWLEDGMENTS}

We thank Junhua $\mathrm{Hu}$ for helping set up the survey locations and for the additional support from members of the Helan Mountain nature reserve. We are also thankful to Dr. Ya He of the East China Normal University for her help with analyses. Lastly, we thank the reviewers' comments that greatly improved this manuscript.

\section{REFERENCES}

Bradley BJ, Chambers KE and Vigilant L (2001). Accurate DNA-based sex identification of apes using non-invasive samples. Conserv. Genet. 2: 179-181.

Brinkman TJ and Hundertmark KJ (2009). Sex identification of northern ungulates using low quality and quantity DNA. Conserv. Genet. 10: 1189-1193.

Bru D, Martin-Laurent F and Philippot L (2008). Quantification of the detrimental effect of a single primer-template mismatch by real-time PCR using the 16S rRNA gene as an example. Appl. Environ. Microbiol. 74: 1660-1663.

Buchan JC, Archie EA, Van Horn RC, Moss CJ, et al. (2005). Locus effects and sources of error in noninvasive genotyping. Mol. Ecol. Notes 5: 680-683.

Cao LR, Liu ZS, Wang XM, Hu TH, et al. (2005). Preliminary study on group characteristics of blue sheep (Pseudois nayaur) in spring and early winter in Helan Mountain, China. Chin. J. Zool. 40: 28-33.

Chen CM, Hu CL, Wang CH, Hung CM, et al. (1999). Gender determination in single bovine blastomeres by polymerase chain reaction amplification of sex-specific polymorphic fragments in the amelogenin gene. Mol. Reprod. Devel. 54: 209-214.

Di Fiore A (2005). A rapid genetic method for sex assignment in non-human primates. Conserv. Genet. 6: 1053-1058.

Ding B, Zhang YP and Ryder OA (1998). Extraction, PCR amplification, and sequencing of mitochondrial DNA from scent mark and feces in the giant panda. Zoo Biol. 17: 499-504.

Ennis S and Gallagher TF (1994). A PCR-based sex-determination assay in cattle based on the bovine amelogenin locus. Anim. Genet. 25: 425-427.

Ensminger AL and Hoffman SM (2002). Sex identification assay useful in great apes is not diagnostic in a range of other primate species. Am. J. Primatol. 56: 129-134.

Findlay I and Quirke P (1996). Fluorescent polymerase chain reaction: Part I. A new method allowing genetic diagnosis and DNA fingerprinting of single cells. Hum. Reprod. Update 2: 137-152.

Griffiths R and Tiwari B (1993). Primers for the differential amplification of the sex-determining region $Y$ gene in a range of mammal species. Mol. Ecol. 2: 405-406.

Griffiths R, Double MC, Orr K and Dawson RJ (1998). A DNA test to sex most birds. Mol. Ecol. 7: 1071-1075.

Gurgul A, Radko A and Słota E (2010). Characteristics of X- and Y-chromosome specific regions of the amelogenin gene and a PCR-based method for sex identification in red deer (Cervus elaphus). Mol. Biol. Rep. 37: 2915-2918.

Liu ZS, Wang XM, Li ZG, Zhai H, et al. (2007). Distribution and abundance of blue sheep in Helan Mountains, China. Chin. J. Zool. 42: 1-8.

Lucchini V, Fabbri E, Marucco F, Ricci S, et al. (2002). Noninvasive molecular tracking of colonizing wolf (Canis lupus) packs in the western Italian Alps. Mol. Ecol. 11: 857-868.

Mossman CA and Waser PM (1999). Genetic detection of sex-biased dispersal. Mol. Ecol. 8: 1063-1067.

Oliveira ML and Duarte JM (2013). Amplifiability of mitochondrial, microsatellite and amelogenin DNA loci from fecal samples of red brocket deer Mazama americana (Cetartiodactyla, Cervidae). Genet. Mol. Res. 12: 44-52.

Pajares G, Álvarez I, Fernández I, Pérez-Pardal L, et al. (2007). A sexing protocol for wild ruminants based on PCR amplification of amelogenin genes AMELX and AMELY (short communication). Arch. Tierz. Dummerstorf 50: $442-446$. 
Pfeiffer I and Brenig B (2005). X- and Y-chromosome specific variants of the amelogenin gene allow sex determination in sheep (Ovis aries) and European red deer (Cervus elaphus). BMC Genet. 6: 16.

Reed JZ, Tollit DJ, Thompson PM and Amos W (1997). Molecular scatology: the use of molecular genetic analysis to assign species, sex and individual identity to seal faeces. Mol. Ecol. 6: 225-234.

Rosel PE (2003). PCR-based sex determination in Odontocete cetaceans. Conserv. Genet. 4: 647-649.

Schliebe SL, Evans TJ, Fischbach AS and Cronin MA (1999). Using genetics to verify sex of harvested polar bears: management implications. Wildl. Soc. Bull. 27: 592-597.

Sipos R, Székely AJ, Palatinszky M, Révész S, et al. (2007). Effect of primer mismatch, annealing temperature and PCR cycle number on 16S rRNA gene-targeting bacterial community analysis. FEMS Microbiol. Ecol. 60: 341-350.

Sullivan KM, Mannucci A, Kimpton CP and Gill P (1993). A rapid and quantitative DNA sex test: Fluorescence-based PCR analysis of X-Y homologous gene amelogenin. Biotechniques 15: 636-638, 640-641.

Taberlet P, Mattock H, Dubois-Paganon C and Bouvet J (1993). Sexing free-ranging brown bears Ursus arctos using hairs found in the field. Mol. Ecol. 2: 399-403.

Waits LP and Paetkau D (2005). Noninvasive genetic sampling of wildlife. J. Wildl. Manag. 69: 1419-1433.

Wang XM, Li M, Tang SX and Liu ZX (1998). A preliminary study of some characters of blue sheep population ecology in spring. Acta Theriol. Sin. 18: 27-33.

Woods JG, Paetkau D, Lewis D, McLellan BN, et al. (1999). Genetic tagging of free-ranging black and brown bears. Wildl. Soc. B 27: 616-627.

Yamauchi K, Hamasaki S, Miyazaki K, Kikusui T, et al. (2000). Sex determination based on fecal DNA analysis of the amelogenin gene in Sika Deer (Cervus nippon). J. Vet. Med. Sci. 62: 669-671.

Yamazaki S, Motoi Y, Nagai K, Ishinazaka T, et al. (2011). Sex determination of sika deer (Cervus nippon yesoensis) using nested PCR from feces collected in the field. J. Vet. Med. Sci. 73: 1611-1616. 